\title{
A New Approach to Use of Modified Soil Profile Meter for Tracking Changes Occurred in Ditches and Furrows Due to Surface Irrigation
}

\author{
R.A. Hegazy* and F.S. Moghanm** \\ *Department of Agricultural Engineering and ${ }^{* *}$ Soil and Water \\ Department, Faculty of Agriculture, Kafr El-Sheikh University, \\ Kafr El-Sheikh, Egypt.
}

\begin{abstract}
A ROSION in ditches and furrows is an important issue associated with surface irrigation, in Egypt, representing a serious problem in Delta region, where most of land still under furrow irrigation system. In this study we describe a new measurment method for different soil furrows and ditches profiles. This method includes a new designed soil profile meter, digital imaging equipment and image tracking \& analyses software. Using such modified soil profile meter can help to observe and measure changes occur in irrigation channels, small ditches and to quantify changes at a specific cross sections within soil furrows. Using image processing and tracking system, we can trace marked points located in fixed level of meter pins, these points have vertical displacements and vary according to existing profiles and cross-sectional shape in different locations, which give the ability to record the presented form of different profiles. The recorded profiles heights for different locations gave perspicuous knowledge about the geometry of furrows and ditches shapes before and after seasonal irrigation process. The differences in measurements for the same location and sites were noted. Designed soil profile meter successfully demonstrated changes in profiles pattern due to surface irrigation erosion in term of height variations. In shallow and wide ditches, the differences in measured heights by soil profile meter after and before irrigation ranged from 0 to $11 \mathrm{~mm}$, while in deep ditches, differences in heights ranged from 0 to $44 \mathrm{~mm}$. With ridge profiles, the measured heights ranged from 0 to $13.88 \%$. High percentage of variation obtained by studying flat top bed furrow changes, the maximum percentage was $17.1 \%$ at the beginning of the furrow line.This clarifies the ability to track and record erosion effect in different furrows and ditches by using soil profile meter as a part of used image processing and tracking system. In addition, soil analyses were done to interpret the results and to measure the credibility of the erosion behavior measurements aquired by the system.
\end{abstract}

Keywords: Soil profile meter, Surface irrigation, Erosion, Soil properties, Ditches, Furrows, Image tracking.

Furrow irrigation is one of the oldest methods of surface irrigation, which is being used in Egypt for a long time. Improvement in furrow irrigation

(fsaadr@yahoo.ca) 
performance and reduction of soil erosion due to furrow irrigation erosion are very important and always connected with the way for measuring furrows and ditches profiles. Different studies on furrow irrigation have been carried out to reduce water losses and erosion related to furrow irrigation, parameters such as furrow stream size, field slope, furrow length, soil type, plant coverage and soil density have been studied (Leib et al., 2005, Szögi et al., 2007, Silva, 2006, Younts et al., 2003 and Mintesinot et al., 2004).

Each type of tillage tool and ditch creating method generate a characteristic oriented roughness and profile pattern which is relatively easy to quantify using simple geometric models. Many common techniques for collecting soil surface data and the analysis of the respective dataset have been discussed. Pin meters are the devices most widely used for their simplicity. They consist in a single probe or a row of probes spaced at pre-established intervals and designed to slide up or down until the tip just touches the soil surface. Pin positions are recorded either electronically or manually (Römkens et al., 1986 and Wagner \& Yiming, 1991). The chief disadvantage to this technique is its destructive impact on the soil surface while recording data in the field. Kornecki et al. (2008) designed and tested a portable meter under typical field conditions; the tool can measure depths up to $500 \mathrm{~mm}$ and easily be modified for usage with large ditches. The device was successfully employed after rainfall events to assess soil erosion/deposition from quarter-drains.

Moreno et al. (2008) conducted study to develop a new method for measuring soil surface roughness that would be more reliable by using the principle underlying shadow analysis is the direct relationship between soil surface roughness and the shadows cast by soil structures under fixed sunlight conditions. He showed that shadow analysis yielded results significantly correlated to the pin meter findings, but with the advantage that the time invested in gathering field data was 12 to 20 times shorter. Another work has been carried out by Borselli and Torri (2010) in order to reproduce reliable rough surfaces able to maintain stable, un-erodible surfaces to avoid changes of retention volume during tests by a set of roughness indices was computed for each surface by using roughness profiles measured with a laser profile meter, and roughness is well represented by quantiles of the Abbot-Firestone curve.

\section{Material and Methods}

Soil profile meter has been developed to determine specific cross sections and furrow profiles in ditches and soil, new futures were added to soil meter to overcome some existing problems related to error measurement in fields. The main concept used with soil meter is to manufacture movable, stable and precise device to measure soil profile and ditches cross-sections without deformation, designed profile meter came with attached wheels to provide smooth movement on ditches side or within soil furrows, this movement ability can be used in field during manually recording of data sets or can be replaced with modified one with

Egypt. J. Soil Sci. 53, No. 2 (2013) 
full control system in case of applying image tracking and processing techniques. For more stability and adequate measurement, it was important to provide a modified frame and tighten methods for movable parts in the soil profile meter.

Based on above mentioned points, the manufactured soil profile meter consisted of a frame holding multiple equally spaced (every $50 \mathrm{~mm}$ ) stainlesssteel pins (2000 mm long) that can be easily positioned and fully controlled by two rows of tie-bolts. Soil profile pins can move freely under gravity or be fully controlled at the time we measure sensitive profile surfaces. The pin housing consisted of two pairs of parallel aluminium bars with $950 \mathrm{~mm}$ length and 850 $\mathrm{mm}$ height, both sides are fixed together and mounted as a frame with 2 pairs of double wheel in each side (Fig. 1). The aluminium pins were located between the aluminium housing; these bars can be easily modified or replaced with another set of different diameter pins. Hydrostatic balance tool was attached to main frame to provide sufficient levelling.
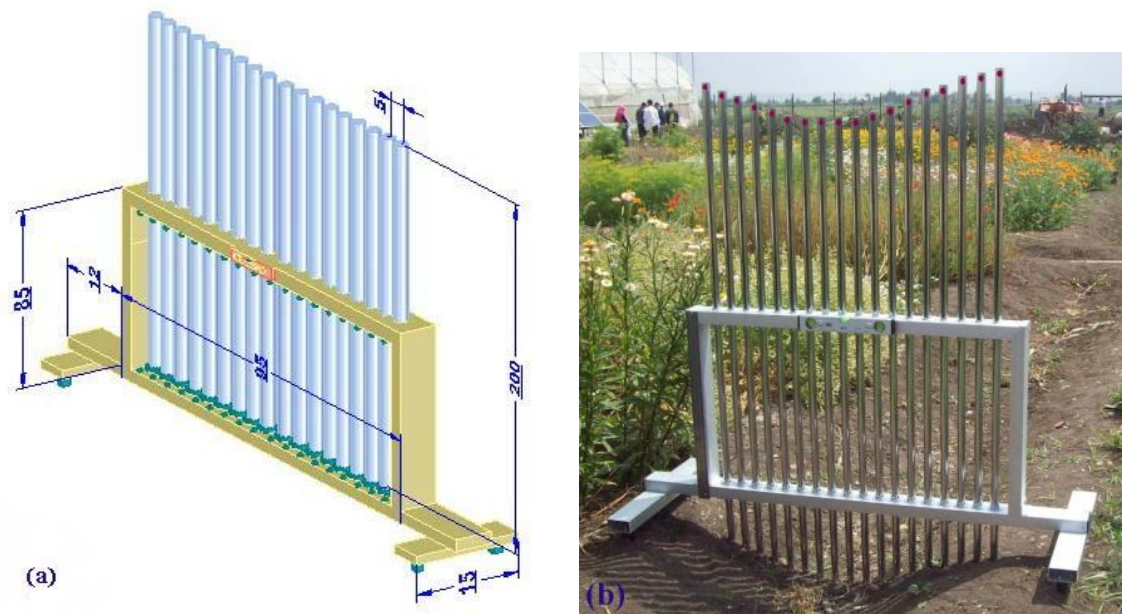

Fig. 1. Trimetric view (a) and photograph (b) of constructed soil profile meter.

Image acquisition and analysis

The video and pictures for image analysis were taken by a high resolution video camera (Sony DCR-HC54E -40x optical zoom/2000x digital zoom), video camera was connected to laptop on the site of measurements as shown in Fig. 2. There is continuous video recording of soil profile meter in different locations and sets of images can be generated by using image tracking and analysis software. Practical implementation of video and image processing done by using Open CV program as a software library projected with Microsoft Visual $\mathrm{C}^{++}$ 2010 Express. Different codes used to simply access, display and trace specified marked points within images. The software classes provide $\mathrm{C}^{++}$video recording and images capturing from video as first step for the process. 


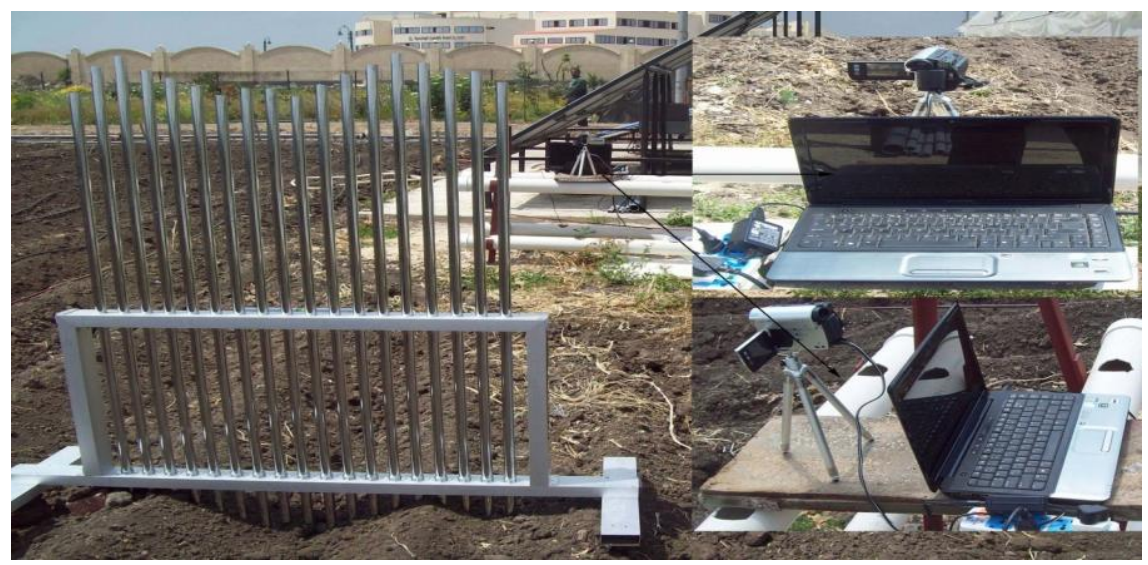

Fig. 2. Camera and sets used in experiments.

\section{Tracking soil profile meter}

At the time we need to recode and determine profiles at fixed location, manually we can adjust pins in soil profile meter above required position without disturbing the profile form. In this case we need only to generate pictures of profile meter after and before adjusting its pins, two pictures will be generated and enough to make a comparison between them to read and analyze the vertical distance of marked points along with profile meter pins.

\section{Profile measurement and differences}

Two locations have been located in two different places, two types of ditches and two different furrows after soil preparation were noticed and marked, in each location one type of ditch and one type of furrow have been chosen. Sketching of profile geometry was done for each ditch and furrow in three different sites along with their length, these sites covered start, middle and end point of their length. Data recorded two times after and before running surface irrigation to address the change occurred in profiles and the distribution of soil erosion along subsections of ditches and furrows. Two common types of ditches were taken as ditches profile example, one type is normally made shallow and wide, and the other one made by farmers and it is deep and has no sidelong edges. Also, two type of soil furrows were profiled, ridges and flat top beds.

\section{Locations of the study sites and analytical data}

The designed profile meter was fabricated in January, 2012 and it used to measure different profiles before irrigation processes same year in February and again after completing the irrigation season in May, 2012 for fixed marked points along with the furrows and ditches. Both site description and analytical data have been done before first use of soil profile meter to describe particle size distribution, soil chemical analysis, aggregation parameters and hydraulic conductivity for each location. Data of description for profiles 1 and 2 showed in Table 1.

Egypt. J. Soil Sci. 53, No. 2 (2013) 
TABLE 1. Profiles description.

\begin{tabular}{|l|l|l|}
\hline \multicolumn{1}{|c|}{ Profile description } & \multicolumn{1}{c|}{ Location 1 } & \multicolumn{1}{c|}{ Location 2 } \\
\hline Location & Soil Kafr El-Sheikh Univ. & Soil Kafr El-Sheikh Univ. \\
\hline Elevation & 5 m a.s.l. & 5 m a.s.l. \\
\hline Soil taxonomy & Torrifluvents & Torrifluvents \\
\hline Soil climate & Torric, Thermic & Torric, Thermic \\
\hline Topography & Flat & Flat \\
\hline Slope & Nearly level & Nearly level \\
\hline Land use & Vegetated soil & Vegetated soil \\
\hline Parent material & Lacustrine deposits & Alluvial deposits \\
\hline Effective soil depth & Moderately deep & Moderately deep \\
\hline Drainage & Well drained & Moderately drained \\
\hline Ground water table & 1060 mm & $>900$ mm \\
\hline
\end{tabular}

Soil physical analysis

To determine particle size distribution, sodium hexameta phosphate as a dispersing agent was used by pipette method (Bandyopadhyay, 2007). For aggregate stability parameters, wet sieving technique described by Bandyopadhyay (2007) was carried out using a set of sieves having 2.00, 1.00, 0.5 and $0.25 \mathrm{~mm}$ screen opining to determine the aggregate size distribution. Water stable aggregates (WSA), aggregation index (AI), optimum size of aggregates (Op. size), mean weight diameter (MWD) and structure coefficient (SC) were calculated and recorded according to Bandyopadhyay (2007).

Soil color in both wet and dry samples was determined with the aid of Munssel color charts (Berms, 2000).

\section{Soil chemical analysis}

In soil paste extract, $\mathrm{Na}^{+}$and $\mathrm{K}^{+}$were estimated, using flame photometer. $\mathrm{Ca}^{++}$and $\mathrm{Mg}^{++}$were determined by the versenate (Na-EDTA) method according to USDA (2004). $\mathrm{CO}_{3}{ }^{=}$and $\mathrm{HCO}_{3}{ }^{-}$were determined volumetrically (USDA, 2004), $\mathrm{Cl}^{-}$was determined following Mohr's method and $\mathrm{SO}_{4}{ }^{=}$was computed from the difference between sum of the cations and the anions (USDA, 2004).

Electric conductivity EC was determined conductmetrically in the soil past extract (Rowell, 1995). Soil reaction $(\mathrm{pH})$ was determined in the 1: 2.5 suspensions (Rowell, 1995). Organic matter content was determined using the modified walkley and Black methods (USDA, 2004). Calcium carbonate was determined using the collin's calcimeter methods (Rowell, 1995). 


\section{Results and Discussion}

Analysis of soil profile geometry for ditches

All measurements have been done by soil profile meter presented in terms of 3$\mathrm{D}$ area charts. For location 1, the geometric shape of shallow and wide ditch in three different sites along with its length before and after seasonal surface irrigation presented in Fig. 3 a at the beginning of the ditch, site 1, the maximum differences in measured height by soil profile meter concentrated in bottom of the ditch with 10, 11 and $9 \mathrm{~mm}$, that's mean there is erosion occurred and affected the origin cross-section of the ditch, while in both sides of the ditch the differences in measurements after and before surface irrigation were less, 7 and $5 \mathrm{~mm}$ were maximum changes in readings in both sides after and before surface irrigation. In some points, there was decreasing in profile meter reading for the same point after and before irrigation, that's mean more sediment in ditch side, it was low but it was measurable, the reason may be due to accumulative of some water residue or mud in these points. At the middle of the ditch, same pattern for erosion effect but the changes occurred in soil profile meter readings were similar in bottom and sides as well. At the end of the ditch, the bottom reading by soil profile meter recorded very less change in the center of the ditch and also changes around the center, maybe due to slow water streaming at the end of the ditch made the effect of water erosion less, the changes recorded in end of the ditch generally were lower than changes notices for middle and beginning of the ditch.

For second type of deep ditch that has and has no sidelong edges in location 2, changes in side measurements for it were very less due to its special constructed shape (Fig. 3b), but there were changes in bottom of the ditch after surface irrigation in all ditch sites, the maximum changes in reading obtained in the beginning where the differences in soil profile meter measurements were high. The values of profile meter differences reached 44,42 and $34 \mathrm{~mm}$ around center point at the beginning of the ditch, while maximum difference in profile meter reading was 30 and $25 \mathrm{~mm}$ for center point at the middle and the end, respectively.

As a comparison between erosion behaviors in above mentioned ditches, the changes occurred in the ditch in location number 1 were less and the differences in soil profile meter readings were little compared to location 2, that was because of water erosion effect was less also in location 1, from locations analytical data in Tables 2, 3 and 4 it was clear that clay percentage in location 1 was higher than location number 2 (Table 2). Also, organic matter (O.M.) in location 1 was higher in all layer compared to the amount of organic matter found in location 2 (Table 3), for drainage condition, location 1 had better drainage system than location 2. In addition, water stable aggregates (WSA), aggregation index (AI), optimum size of aggregates (Op. size), mean weight diameter (MWD) and structure coefficient (SC) for location 1 were always better location 2 as presented in Table 4. All soil physical and chemical characteristics as we saw lead to more sustainability for the soil against erosion in location 1 more than location 2 and measurements done by soil profile meter cleared that also and showed the differences due to erosion in both locations.

Egypt. J. Soil Sci. 53, No. 2 (2013) 

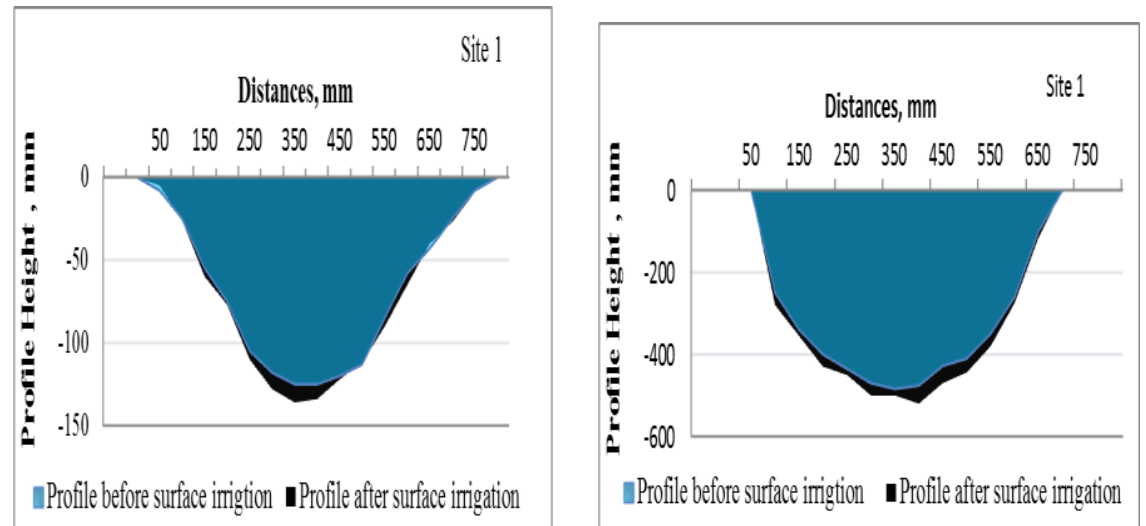

Mrofile before sufface inigtion $\mathbf{\Delta}$ Profile after sufface inigation
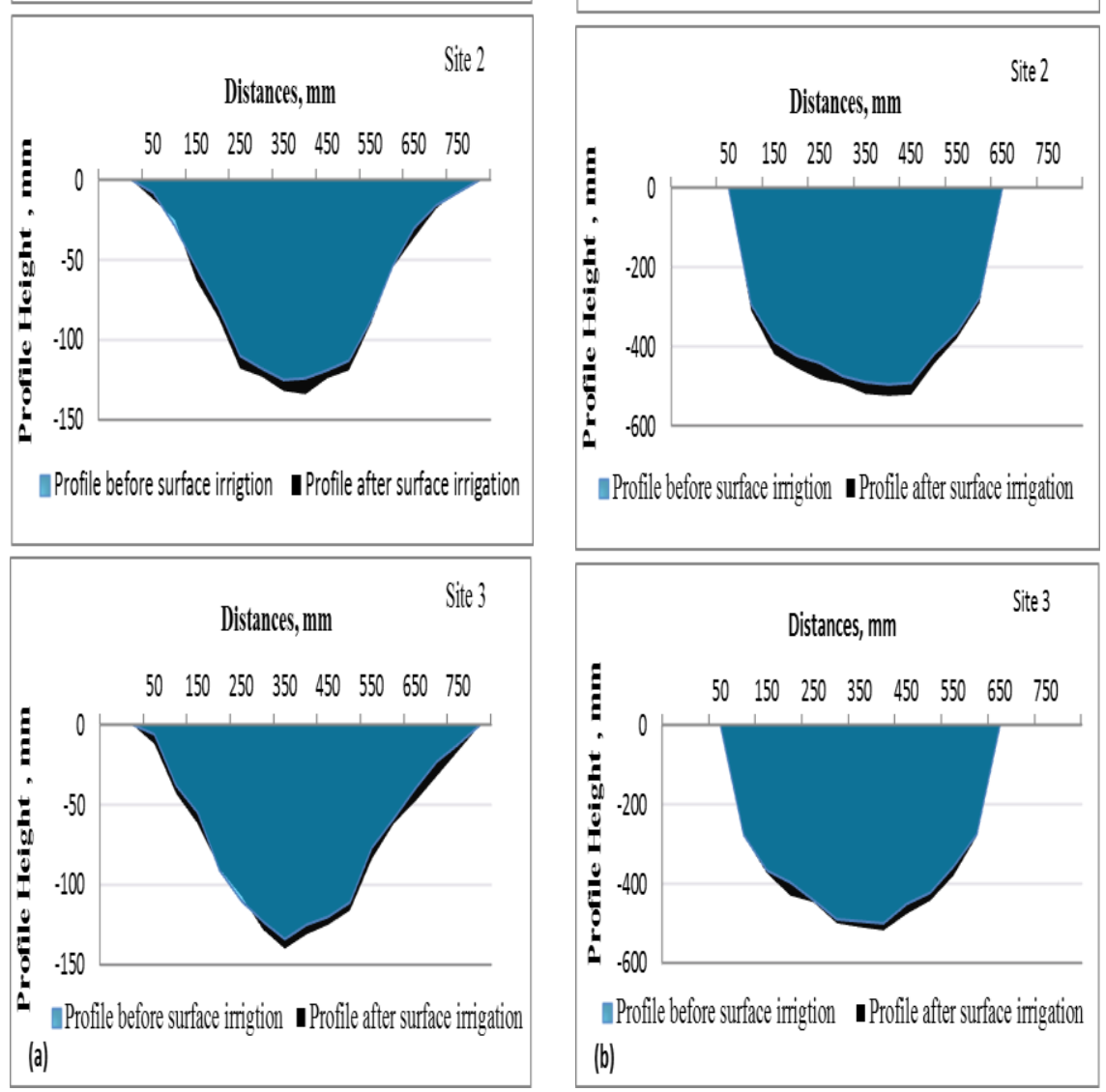

Fig. 3. Differences in geometric shape between origin and formed ditch after surface irrigation for three different locations: (a) shallow and wide ditch in location 2 (b) deep and has no sidelong edges ditch in location 1. 
TABLE 2 . Particle size distribution and $\mathrm{CaCO}_{3}$ content.

\begin{tabular}{|c|c|c|c|c|c|c|c|c|c|c|}
\hline \multirow{3}{*}{ Depth, mm } & \multirow{2}{*}{\multicolumn{2}{|c|}{$\begin{array}{c}\text { Sand } \% \\
2-0.02\end{array}$}} & \multirow{2}{*}{\multicolumn{2}{|c|}{$\begin{array}{c}\text { Silt \% } \\
\text { 0.02-0.002 }\end{array}$}} & \multirow{2}{*}{\multicolumn{2}{|c|}{$\begin{array}{l}\text { Clay \% } \\
<0.002\end{array}$}} & \multirow{2}{*}{\multicolumn{2}{|c|}{$\begin{array}{c}\text { Texture } \\
\text { Class }\end{array}$}} & \multirow{2}{*}{\multicolumn{2}{|c|}{$\frac{\mathrm{CaCO}_{3}}{\%}$}} \\
\hline & & & & & & & & & & \\
\hline & $\mathbf{L} 1^{\bullet}$ & L2*• & L1 & L2 & L1 & $\mathbf{L 2}$ & L1 & L2 & L1 & L2 \\
\hline $\begin{array}{cc}0-250 & \text { for } L 1 \\
0-200 & \text { for } L 2\end{array}$ & 1.50 & 1.46 & 50.02 & 51.3 & 48.3 & 47.2 & Silty clay & Silty clay & 2.2 & 1.4 \\
\hline $\begin{array}{ll}0-250 & \text { for } L 1 \\
200-750 & \text { for } L 2\end{array}$ & 1.70 & 1.75 & 69.87 & 71.82 & 28.43 & 26.43 & $\begin{array}{l}\text { Silty clay } \\
\text { loam }\end{array}$ & $\begin{array}{l}\text { Silty } \\
\text { loam }\end{array}$ & 0.6 & 1.8 \\
\hline $\begin{array}{ll}0-250 & \text { for } L 1 \\
750-900 & \text { for } L 2\end{array}$ & 2.03 & 2.13 & 69.82 & 67.72 & 28.15 & 30.15 & $\begin{array}{l}\text { Silty clay } \\
\text { loam }\end{array}$ & $\begin{array}{l}\text { Silty clay } \\
\text { loam }\end{array}$ & 0.1 & 1.8 \\
\hline
\end{tabular}

L1: Location 1. - L2: Location 2.

TABLE 3. Soil chemical analysis.

\begin{tabular}{|c|c|c|c|c|c|c|c|c|c|c|c|c|c|}
\hline \multirow{2}{*}{ Location } & \multirow{2}{*}{$\begin{array}{c}\text { Depth, } \\
\text { mm }\end{array}$} & \multirow{2}{*}{$\frac{\text { SP }}{\%}$} & \multicolumn{4}{|c|}{ Soluble cation meq/L* } & \multicolumn{4}{|c|}{ Soluble a nine meq/L* } & \multirow{2}{*}{$\begin{array}{c}\mathrm{pH} \\
1: 2.5 \\
\text { susp. }\end{array}$} & \multirow{2}{*}{\begin{tabular}{|c|}
$E C^{*}$ \\
$d S /$ \\
$m$
\end{tabular}} & \multirow{2}{*}{\begin{tabular}{|c|} 
O.M \\
$\%$
\end{tabular}} \\
\hline & & & $\mathrm{Ca}^{++}$ & $\mathbf{M g}^{++}$ & $\mathrm{Na}^{++}$ & $\mathbf{K}^{+}$ & $\mathrm{CO}_{3}^{--}$ & $\mathrm{HCO}_{3}^{-}$ & $\mathrm{CL}^{-}$ & $\mathrm{SO}_{4}^{--}$ & & & \\
\hline \multirow{3}{*}{$\mathrm{L} 1^{\bullet}$} & $0-250$ & 108.6 & 2.0 & 2.8 & 6.4 & 0.3 & 1.5 & 3.2 & 6.1 & 0.7 & 8.05 & 1.15 & 1.89 \\
\hline & $\begin{array}{c}250- \\
900\end{array}$ & 127.6 & 2.8 & 4.6 & 9.7 & 0.8 & 1.5 & 5.0 & 9.5 & 2.7 & 8.25 & 1.77 & 1.5 \\
\hline & $\begin{array}{l}900- \\
1060\end{array}$ & 168.2 & 3.2 & 4.8 & 9.6 & 1.2 & 1.0 & 4.8 & 10.2 & 2.8 & 8.15 & 1.88 & 0.69 \\
\hline \multirow{3}{*}{$\mathrm{L} 2{ }^{\bullet \bullet}$} & $0-200$ & 95.87 & 1.6 & 2.6 & 8.2 & 0.4 & 1.5 & 3.5 & 8.4 & 0.4 & 7.78 & 1.28 & 1.61 \\
\hline & $20-750$ & 98.56 & 2.8 & 4.2 & 14.2 & 0.8 & 0.8 & 4.4 & 15.6 & 1.20 & 7.85 & 2.20 & 0.88 \\
\hline & $\begin{array}{c}750- \\
900\end{array}$ & 102.75 & 2.2 & 4.6 & 15.4 & 0.8 & 0.0 & 4.5 & 16.0 & 2.5 & 7.78 & 2.3 & 0.49 \\
\hline
\end{tabular}

TABLE 4. Aggregation parameters and hydraulic conductivity.

\begin{tabular}{|c|c|c|c|c|c|c|c|c|c|c|c|c|}
\hline \multirow{2}{*}{ Depth, mm } & \multicolumn{2}{|c|}{ WSA \% } & \multicolumn{2}{|c|}{ O.P. mm } & \multicolumn{2}{|c|}{ SC } & \multicolumn{2}{|c|}{ MWD } & \multicolumn{2}{|c|}{ AI } & \multicolumn{2}{|c|}{ H.C } \\
\hline & L1 & L2 & L1 & L2 & L1 & L2 & L1 & L2 & L1 & L2 & L1 & L2 \\
\hline $\mid \begin{array}{ll}0-250 & \text { for } L 1 \\
0-200 & \text { for } L 2\end{array}$ & 43.782 & 41.74 & 34.641 & 23.662 & 0.689 & 0.716 & 0.538 & 0.5628 & 0.2689 & 0.2814 & 1.05 & 0.46 \\
\hline $\begin{array}{lr}0-250 & \text { for } L 1 \\
200-750 & \text { for } L 2\end{array}$ & 40.621 & 38.857 & 25.043 & 19.241 & 0.684 & 0.6355 & 0.299 & 0.2943 & 0.1497 & 0.1472 & 0.98 & 0.92 \\
\hline $\begin{array}{lr}0-250 & \text { for } L 1 \\
750-900 & \text { for } L 2\end{array}$ & 47.284 & 46.575 & 15.262 & 27.175 & 0.897 & 0.8718 & 1.371 & 0.5215 & 0.6856 & 0.2607 & n.d & n.d \\
\hline
\end{tabular}

Egypt. J. Soil Sci. 53, No. 2 (2013) 


\section{Analysis of soil erosin for ridge}

For ridge in location 1, after using soil profile meter to measure different ridge profile points on the surface, the geometric shapes in Fig. 4a showed that there was erosion effect along with ridge length in end, middle and beginning of the furrow. The maximum differences in measurements were about $25 \mathrm{~mm}$ at the beginning in the bottom followed by 22 and $15 \mathrm{~mm}$ for the middle and end of the furrow, respectively. The differences in readings recorded by the soil profile meter for the furrow sides were very less in all furrow sites, and there were six points on ditch sides gave same profile meter reading before and after surface irrigation.
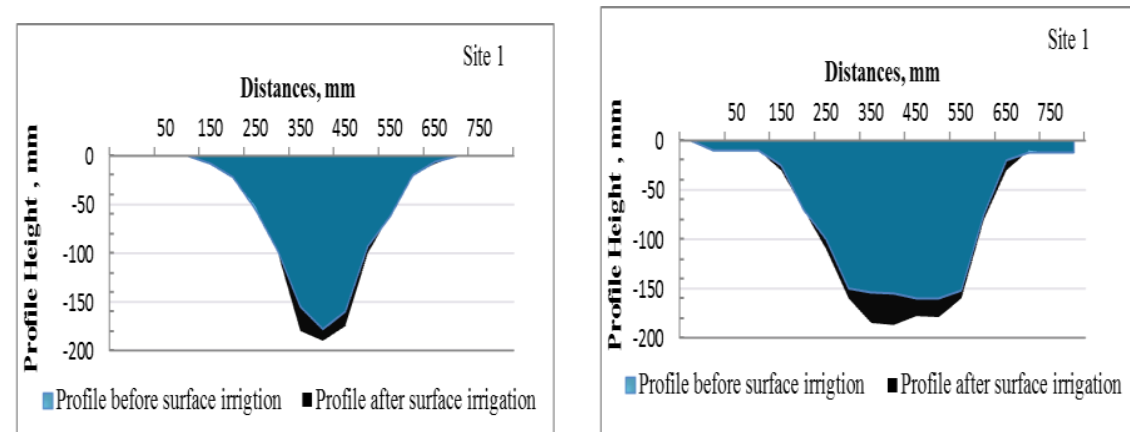

Profile before surface imigtion - Profile after surface imigation
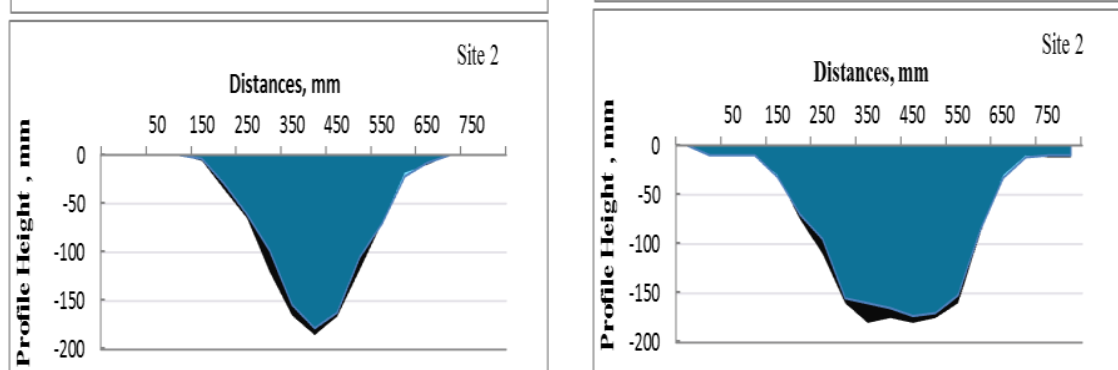

-Profile before surface irrigtion $\mathbf{D r}$ Prile after surface imigation

-Profile before surface irrigtion $\mathbf{\Delta P r o f i l e ~ a f t e r ~ s u r f a c e ~ i r r i g a t i o n ~}$
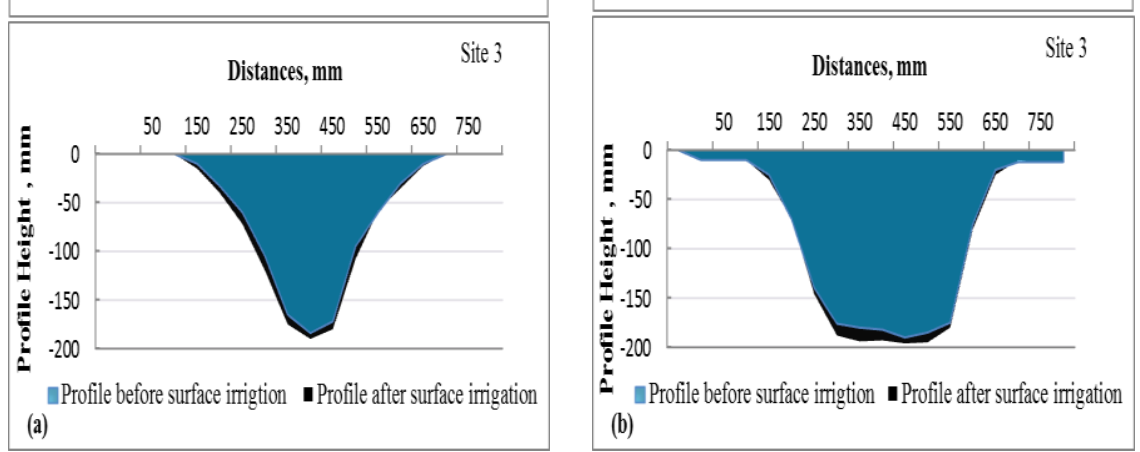

Fig. 4. Differences in geometric shape between origin and formed furrow after surface irrigation for three different locations, (a) ridge profile in location 2 (b) flat top beds in location 1.

Egypt. J. Soil Sci. 53, No.2 (2013) 
For flat top bed furrow in location 2, same pattern was observed from data, where in the beginning of the furrow line there was maximum difference in profile meter reading followed by the middle of the furrow then the line end. Major changes done around center points in furrow bottom, but changes in both sides of the furrow were less maybe because running water in furrow remain only in bottom and don't cover all side height.

From soil analysis, again we can see that the better soil analysis results for location 1 presented in Tables 2, 3 and 4 played an important rule to slightly prevent erosion in this location as it was clear from soil profile meter readings.

\section{Conclusion}

Using soil profile meter to record different soil profiles is an effective method to referee to any changes could happen in soil surface. It was clear that the modified soil profile meter gave adequate results to measure different heights for different profiles, and this gave us idea about the changes happened in different locations related to seasonal surface irrigation in land. Matching between data collected by profile meter and expected behavior of erosion according to soil physical and chemical analysis increased the credibility of the modified device. Using image tracking and analyses technique was very operative method to measure soil profiles with minimum disturbance of soil surfaces, which is important to achieve a better understanding of the behavior of a soil under different conditions. In addition, designed profile meter is very flexible and can be used for a wide range to measure different type of furrows, ditches, rills and drainage canals.

Acknowledgement : The authors thank the Ag. Eng. Department technicians for their help during the tests and greatly indebted to Prof. Safwat. M. Shams, Soil Department, Faculty of Agricultural, Kafr El-Sheikh University, for his help in revising the manuscript.

\section{References}

Bandyopadhyay, P. (2007) "Soil Analysis", HARDCOVER ISBN- 13: $9788189729691 .$, $286 \mathrm{p}$.

Berms, R.S. (2000) "Billmeyer and Saltzman's Principles of Color Technology", New York, John Wiley and Sons.

Borselli, L. and Torri, D. (2010) Soil roughness, slope and surface storage relationship for impervious areas. Journal of Hydrology 393 : 389-400. A., 15: 382-409, Amer. Soc. Agron. Madison, Wisconsin, USA.

Kornecki , J. et al. (2008) Potencjat rozwojowy polskich MSP, Polish Agency for Enterprise Development, Warsaw.

Egypt. J. Soil Sci. 53, No. 2 (2013) 
Leib, B.G., Redulla, C.A., Stevens, R.G., Matthews, G.R. and Strausz, D.A. (2005) Erosion control practices integrated with polyacrylamide to reduce sediment loss in furrow irrigation. Appl. Eng. Agr. 21: 595-603.

Mintesinot, B., Verplancke, H., Van Ranst, E. and Mitiku, H. (2004) Examining traditional irrigation methods, irrigation scheduling and alternate furrows irrigation on vertisols in northern Ethiopia. Agric. Water Manage. 64 (1): 17-27.

Moreno, R.G., Saa Requejo, A., Tarquis Alonso, A.M., Barrington, S. and Díaz, M.C. (2008) Shadow analysis: A method for measuring soil surface roughness. Geoderma 146 : 201-208

Römkens, M.J.M., Singarayar, S. and Gantzer, C.J. (1986) An automated non contact surface profile meter. Soil Tillage Res. 6: 193-202.

Rowell, D.L. (1995) "Soil Sciences Methods and Applications", Library of Congress Cataloging-in-Publication Data , New York, NY., 10158-USA.

Silva, L.L. (2006) The effect of spray head sprinklers with different deflector plates on irrigation uniformity, runoff and sediment yield in a Mediterranean soil. Agric. Water Manage. 85 (3): 243-252.

Szögi, A.A., Leib, B.G., Redulla, C.A., Stevens, R.G., Mathews, G.R. and Strausz, D.A. (2007) Erosion control practices integrated with polyacrylamide for nutrient reduction in rill irrigation runoff.

USDA (2004) "Soil Survey Laboratory Methods Manual", Soil Survey Investigation Report No. 42 , Version 4.

Wagner, L.E. and Yiming, Y. (1991) Digitization of profile meter photographs. Trans. ASAE 34 (2) : 412-416.

Younts, C.D., Eisenhauer, D.E. and Varner, D. (2003) Managing furrow irrigation systems.

(Received 25/8/2013;

accepted 25/12/2013) 


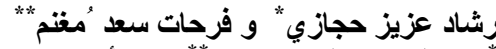

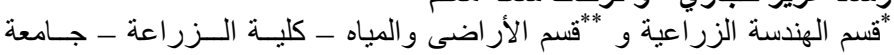

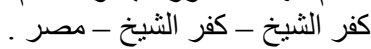

عملية نحر التربة في الخنادق و الأخاديد هي قضية هامة تتعلق بالري السطحي في

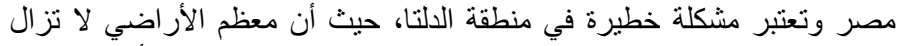

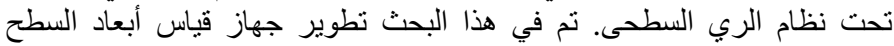

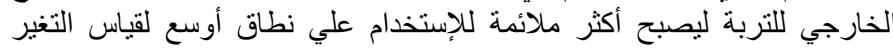

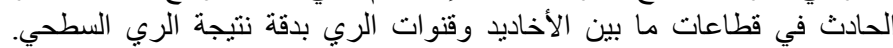

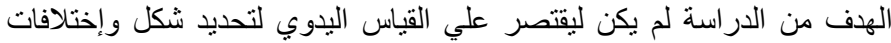

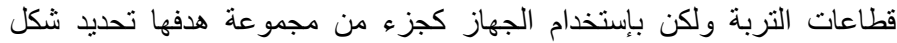

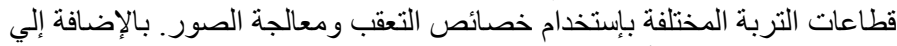

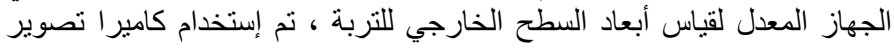

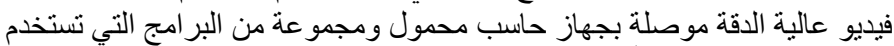
في تحليل الصور حسابياً.

تم قياس التغير الحادث في النقاط الممثلة لثكل القطاع عند ثلاثة أماكن مختلفة

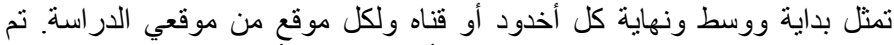

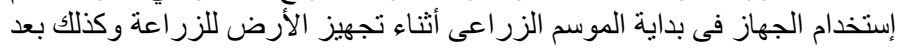

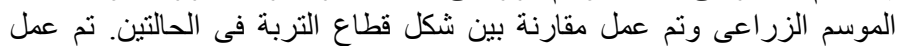

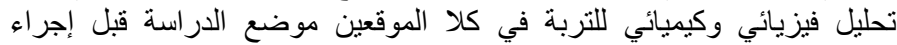

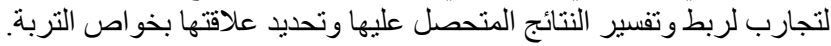

اثبتت الدراسة أن هناك تغير ات حدثت في قيم و أبعاد القطاعات كما أن هذه إنها

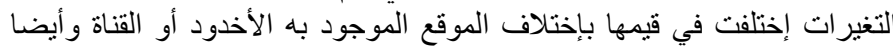

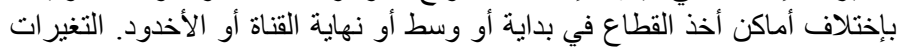

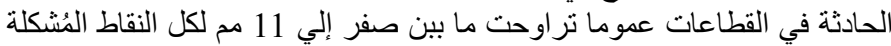

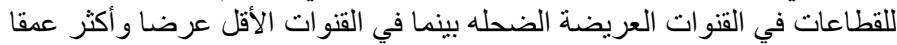

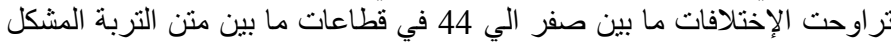

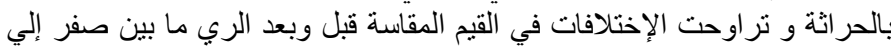

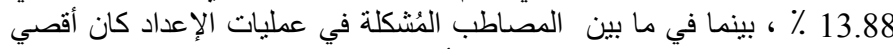

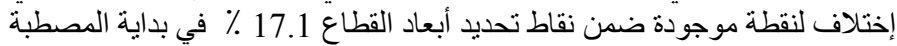

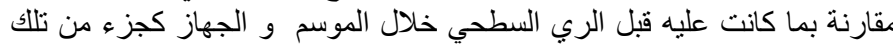

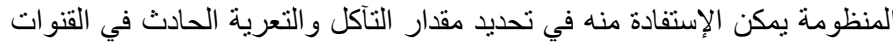

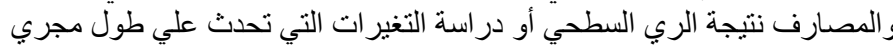

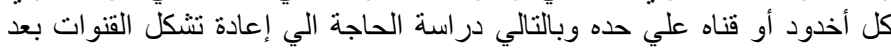

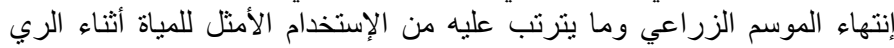

